\title{
IMPROVEMENT OF BIOETHANOL PRODUCTION FROM RICE HUSKS
}

\author{
ANA MARÍA ARISMENDY PABÓN, ${ }^{*}$ FERNANDOE. FELISSIA,${ }^{* *}$ CAROLINA M. MENDIETA, ${ }^{* *}$ \\ ESTER CHAMORRO ${ }^{* * *}$ and MARÍA CRISTINA AREA ${ }^{* *}$ \\ "National University of Misiones, Félix de Azara 1552, Misiones, Argentina \\ ** IMAM, UNaM, CONICET, FCEQYN, Pulp and Paper Program (PROCYP), Félix de Azara 1552, \\ (3300) Posadas, Misiones, Argentina \\ ***IMIT, UTN-CONICET, QUIMOBI, French 414, Resistencia, Argentina \\ Corresponding author: A. M. Arismendy Pabón, anaarismendy25@gmail.com
}

Received March 19, 2020

This work aimed to compare the production of bioethanol from rice husk through simultaneous hydrolysis and fermentation process (SSF) with that through hydrolysis followed by fermentation process (SHF). The raw material was pretreated under mild conditions with sodium hydroxide. Initially, the influence of particle size was evaluated in the enzymatic hydrolysis of pretreated milled and unmilled husk. Subsequently, the efficiencies of Saccharomyces cerevisiae IMR 1181 (SC 1181) and Saccharomyces cerevisiae IMR 1507 (SC 1507) yeasts were compared using the SSF process. Finally, the SSF and SHF processes were compared using the SC 1181 yeast. Although a little more glucose was generated using ground husk (36.6\% vs. $35.5 \%)$, grinding costs have to be also considered. The SC1507 yeast performed best at all times. The bioethanol yields for SHF and SSF with SC 1181 were of $35.3 \%$ and $38.2 \%$, respectively. Maximum yields in SSF were of 43.9\% for SC 1507 and 38\% for SC 1181.

Keywords: rice husk, simultaneous hydrolysis and fermentation, hydrolysis followed by fermentation, yeast, yields

\section{INTRODUCTION}

Biofuels, such as bioethanol, are interesting alternatives to surpass the global energy crisis caused by the depletion of fossil fuels and environmental problems, such as global warming. ${ }^{1}$ Since the raw materials for biofuel production are also used for food, this has generated economic, political, and social controversies. The production of first-generation bioethanol from sugarcane and corn is very high to be able to supply the needs of the food and biofuel sectors. ${ }^{2}$ Therefore, alternatives have been proposed, such as the production of secondgeneration biofuels from raw lignocellulosic materials. Rice straw and husk are residues of agro-industrial activities. They are composed of more than $50 \%$ cellulose and hemicelluloses, making them suitable for the production of biofuels. $^{3}$

Rice is the most cultivated cereal in the world, especially in Asian countries. Its production generates large amounts of rice husk as lignocellulosic residue. ${ }^{4}$ According to a projection of FAO made in 2017, 24.0 million tons of rice in the years 2018/2019 were expected to be produced in South American countries, such as Brazil, Bolivia, Colombia, Ecuador and
Argentina. ${ }^{5}$ The biomass generated as a residue (straw, husks) is generally eliminated by burning, with negative environmental impacts. ${ }^{6}$

Cellulose, the major component of lignocellulosic biomass, is formed by large glucose chains. Hemicelluloses are formed by chains of several sugars with five and six atoms of carbon, whereas lignin is an aromatic complex. ${ }^{7}$

For bioethanol production, because of the structure of lignocellulosic materials, it is necessary to pretreat the biomass before enzymatic hydrolysis and glucose fermentation. ${ }^{8}$ The pretreatment is performed for removing a certain amount of lignin and hemicelluloses to improve the accessibility of the enzymes to cellulose. $^{9,10}$ Different techniques have been applied to pretreat the lignocellulosic materials, involving the use of acids, alkalis, enzymes, and (or) microorganisms, ultrasound, and plasma. ${ }^{11,12}$ Moderate and high temperature and pressure have been tried. ${ }^{13}$ Alkaline pretreatment is used under milder conditions than acid pretreatments. ${ }^{14}$ The most important reactions in alkaline pretreatment include lignin and hemicelluloses dissolution and de-esterification of the intermolecular ester bonds, increasing the porosity of the material. ${ }^{15,16}$ The 
more frequently used reagents are sodium, ammonia and calcium hydroxides. Sodium hydroxide attacks the linkage between lignin and hemicelluloses and is effective for the cleavage of the ester and carbon to carbon bonds in lignin molecules. It contributes to an increase in the internal surface area and crystallinity, due to the swelling that occurs in the lignocellulosic biomass. ${ }^{16,17}$

The hydrolysis produces the breakdown of the polymers of cellulose and hemicelluloses in monomers. ${ }^{18}$ In the first case, it implies a synergistic reaction between the enzymatic complex and cellulose to produce its degradation to fermentable sugars, especially glucose. ${ }^{19}$ Endoglucanases (Egs) attack the areas of low crystallinity of the cellulose and produce ends with free chains, whilst exo-glucanases (cellobiohydrolases, $\mathrm{CBH}$ ) cut the ends of the free chains by eliminating the cellobiose (glucose dimer) units using exo-glucanases. ${ }^{19}$

The most commonly used yeast in industrial fermentations is Saccharomyces cerevisiae, followed by others, such as Kluyveromyces marxianus, also important in the agro and industrial sectors. $^{20}$ In the hydrolysis followed by fermentation (SHF), the processes are carried out separately and consecutively, whilst in the simultaneous hydrolysis and fermentation (SSF), both processes are carried out simultaneously in the same reactor. The advantages offered by the SSF process, as compared to the SHF one, are the immediate consumption of sugars by microorganisms, a lower risk of microbial contamination, $^{21}$ and accumulation of sugars, reducing costs when using a single reactor with less processing time. ${ }^{22}$

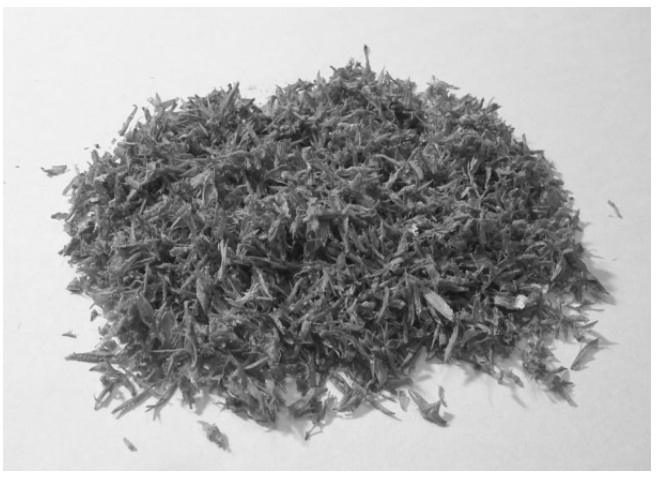

a)
Recent works on the production of bioethanol from rice straw and rice husks have used recombinant yeasts to improve the yields of bioethanol production. Saccharomyces cerevisiae has been the most robust yeast for this use. Genetic modifications of this microorganism have been made for it to generate enzymes and ferment sugars with five carbon atoms. ${ }^{23,24}$

This work aims to compare the production of bioethanol from rice husk through the simultaneous hydrolysis and fermentation process (SSF) and the hydrolysis followed by fermentation process (SHF). The influence of particle size on the enzymatic hydrolysis of rice husk was evaluated using pretreated milled and unmilled husk. In addition, the efficiencies of Saccharomyces cerevisiae IMR 1181 (SC 1181) and Saccharomyces cerevisiae IMR 1507 (SC 1507) yeasts were compared, using the SSF process.

\section{EXPERIMENTAL}

\section{Materials}

Rice husk was provided by Las Palmas from a rice field in Chaco, Argentina. Part of the husk was subjected to mechanical treatment in a knife mill, to reduce particle size, and sieved using a $2 \mathrm{~mm}$ square mesh sieve. Both types of rice husk, milled and unmilled, were pretreated with $3 \%$ w/V sodium hydroxide and $10 \% \mathrm{w} / \mathrm{V}$ biomass in an autoclave at $121{ }^{\circ} \mathrm{C}$ for 1 hour. ${ }^{25}$ Figure 1 shows both studied materials.

Cellic ${ }^{\circledR}$ CTec2 enzymes from Novozymes were used (enzymatic activity: $110 \mathrm{FPU} / \mathrm{mL}$ ). The yeasts Saccharomyces cerevisiae IMR 1181 (SC 1181) and Saccharomyces cerevisiae IMR 1507 (SC 1507) were donated by the Institute of Regional Medicine, Chaco, Argentina.

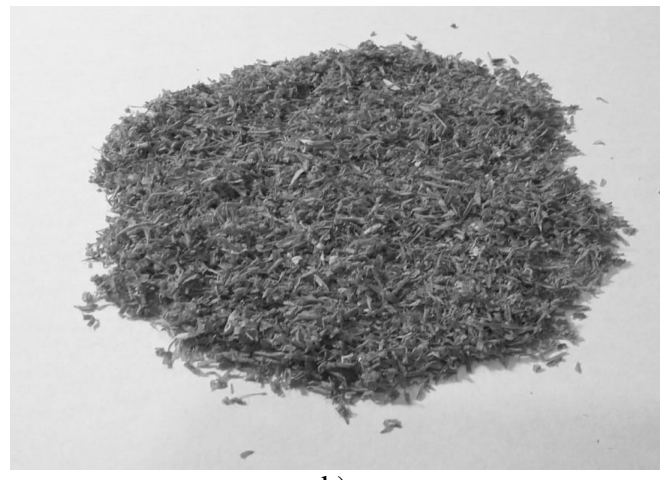

b)

Figure 1: a) Unmilled pretreated rice husk, and b) milled pretreated rice husk 


\section{Characterization of rice husk}

The milled and unmilled pretreated rice husks were characterized using NREL (National Renewable Energy Laboratory) standards: (a) moisture content and volatile substances (NREL/TP-510-42), ${ }^{26}$ (b) content of extractive substances soluble in water and ethanol (NREL/TP 510-4262), ${ }^{18,27}$ (c) carbohydrates and lignin (NREL/TP-510-42618), ${ }^{28}$ and (d) ash (NREL/TP-510-42622). ${ }^{29}$

\section{Determination of enzymatic activity}

The enzymatic activity expressed in FPU (Filter Paper Unit), which is the ability of the enzyme to saccharify cellulose to glucose, was determined following the procedure detailed by IUPAC. ${ }^{30}$

\section{Preparation of pre-inoculum and inoculum}

For the pre-inoculum and inoculum, $100 \mathrm{~mL}$ of YPD liquid medium (yeast extract, peptone, and glucose) were prepared in the following concentrations: yeast extract $10 \mathrm{~g} / \mathrm{L}$, peptone $20 \mathrm{~g} / \mathrm{L}$, and glucose $20 \mathrm{~g} / \mathrm{L}$, as proposed by the standard for SSF (NREL/TP-510-42630). ${ }^{31}$ It was also supplemented with micronutrients, such as potassium phosphate $5 \mathrm{~g} / \mathrm{L}$, ammonium chloride $1.5 \mathrm{~g} / \mathrm{L}$, and magnesium sulfate heptahydrate $0.65 \mathrm{~g} / \mathrm{L}$, according to a protocol adapted for SSF. ${ }^{32}$ A $2 \mathrm{~mL}$ sample of SC 1181 cells was added to $10 \mathrm{~mL}$ of the liquid medium until an optical density of 0.8 was obtained, and the remaining $90 \mathrm{~mL}$ of the liquid medium was incorporated until a density of 0.73 was obtained, which would be part of the inoculum. The reading of optical density was performed by spectrophotometry at $640 \mathrm{~nm}$, as proposed by the standard for SSF (NREL/TP-510-42630). ${ }^{31}$ The inoculum was formed with the obtained $100 \mathrm{~mL}$.

The process of formation of the pre-inoculum and inoculum lasted approximately 25 hours. The same procedure realized by SSC 1181 was performed for yeast SC 1507 , at $34{ }^{\circ} \mathrm{C}$ and $180 \mathrm{RPM}$, according to agitation ranges optimized for hydrolysis and fermentation. ${ }^{33}$ This agitation was only used for the pre-inoculum and inoculum in the fermentation processes.

\section{Enzymatic hydrolysis}

The hydrolysis (EH) was performed in duplicates, using the optimized conditions reported in previous work: $^{33} \quad 30 \mathrm{FPU} / \mathrm{g}$ substrate (glucans), $2 \% \mathrm{w} / \mathrm{v}$ substrate, $37{ }^{\circ} \mathrm{C}, \mathrm{pH} 5.0,130 \mathrm{rpm}$ stirring, 13 hours, and $0.3 \mathrm{~g} / \mathrm{L}$ Tween 80 surfactant.

The work volume used to perform the $\mathrm{EH}$ was 100 $\mathrm{mL} ; 50 \mathrm{~mL}$ of sodium citrate was used as buffer in a concentration of $0.1 \mathrm{M}$, and approximately $48 \mathrm{~mL}$ of distilled water, according to the protocol proposed in the NREL standard for EH (NREL/TP-510-42629). ${ }^{34}$ To improve saccharification, Tween 80 surfactant was used to homogenize the enzymes. Sugars (glucose, xylose, arabinose) were quantified by liquid chromatography (HPLC), using an Aminex HPX-87H column (BIORAD). The chromatographic conditions were as follows: $4 \mathrm{mM} \mathrm{H}_{2} \mathrm{SO}_{4}$ as eluent, $0.6 \mathrm{~mL} / \mathrm{min}$, $35^{\circ} \mathrm{C}$ and diode refractive index and array detectors.

The glucose yields in the $\mathrm{EH}$ of pretreated rice husk (PRH) were calculated using Equations 1 and 2:

Theoretical glucose available $(\mathrm{g} / \mathrm{L})=(\mathrm{g}$ dried husk $\times$ glucans in $\mathrm{PRH} / 0.9) \times 10$

Glucose yield $(\%)=\mathrm{g} / \mathrm{L}$ glucose obtained $/ \mathrm{g} / \mathrm{L}$ theoretical glucose $\times 100$

\section{Hydrolysis followed by fermentation}

The EH supernatant of the treatment on milled and pretreated husk was extracted from the solid fraction by decantation. The supernatant was supplemented with $10 \mathrm{~g} / \mathrm{L}$ yeast extract and $10 \mathrm{~g} / \mathrm{L}$ peptone, as proposed by the standard (NREL/TP-510-42630). ${ }^{31}$ Then, $10 \% \mathrm{v} / \mathrm{v}$ of the total work volume $(100 \mathrm{~mL})$ was inoculated, according to the adapted protocol for $\mathrm{SSF}^{32}$

In the SHF process, $90 \mathrm{~mL}$ of the enzyme hydrolyzate was loaded, followed by $10 \mathrm{~mL}$ of inoculum. The SHF process was realized at 130 RPM and lasted 24 hours.

\section{Simultaneous hydrolysis and fermentation}

SSF was performed in a total volume of $100 \mathrm{~mL}$, supplemented with buffer, distilled water, yeast, and peptone extract, and inoculated with $10 \% \mathrm{v} / \mathrm{v}$ of the total work volume, according to the protocol adapted for SSF. ${ }^{32}$ It was done similarly to the procedure for SHF with pretreated and milled rice husk. The SSF process was realized at 130 RPM and lasted 72 hours.

The bioethanol yields obtained in the SHF and SSF processes were calculated using Equation 3:

Bioethanol yield $(\%)=$ Ethanol produced $(\mathrm{g} / \mathrm{L}) / 0.511 \times$ Glucose in PRH $(\mathrm{g} / \mathrm{L}) \times 100$

\section{Statistical analysis}

Multifactorial ANOVA and Multiple range test (LSD) were carried out using the Startgraphics Centurion program. All analyses were performed with a $95 \%$ confidence level.

\section{RESULTS AND DISCUSSION Characterization of rice husk}

The pretreatment yield was $51.2 \pm 2.7 \%$. The results corresponding to the characterization of both types of pretreated rice husk (both milled and unmilled) are shown in Table 1. The data in Table 1 show that there is no significant difference in the chemical composition of milled and unmilled husks after the pretreatment. The pretreated rice husk still contains $15 \%$ lignin and $20 \%$ hemicelluloses, which can hinder the accessibility of the enzymes to cellulose, producing low hydrolysis yields. The main effects 
of the pretreatment are the solubilization of inorganic substances and the partial removal of lignin. Rice straw seems to be less recalcitrant than rice husk, being more prone to delignification, and allowing to obtain higher cellulose percentages on biomass $(>60 \%)$, although in general, authors report more energetic conditions. $^{35,36}$ Other authors working with rice husks under similar alkaline conditions, but including hydrogen peroxide, obtained somewhat higher cellulose content $(56 \%) .{ }^{37}$ In this study, the alkaline conditions used were mild $(3 \% \mathrm{w} / \mathrm{V}$ alkali, $10 \% \mathrm{w} / \mathrm{V}$ biomass, for $1 \mathrm{~h}$, at $121{ }^{\circ} \mathrm{C}$ ), so the effects on delignification and porosity gain were also light. To obtain higher cellulose availability, the pretreatment conditions have to be modified.

\section{Enzymatic hydrolysis \\ Influence of particle size}

The production and yield of sugars in the EH of the milled and unmilled rice husk are presented in Table 2. The maximum glucose hydrolysis yields for both the milled and unmilled pretreated husks are approximately 36.6 and $35.5 \%$ (Table 2) obtained after $12 \mathrm{~h}$ of hydrolysis. The multifactor ANOVA indicates that time (h) significantly affects the $\mathrm{EH}(\mathrm{p}=0.0000)$.

Figure 2 shows that the maximum values of glucose obtained from both milled and unmilled rice husks does not present significant differences. In milled rice husk, the whole process is faster, reaching the maximum total sugars (glucose, xylose and arabinose) production values at $12 \mathrm{~h}$. The glucose produced from the milled and unmilled rice husk drops after $12 \mathrm{~h}$, but the sugar generation from unmilled rice husk continues to grow until $24 \mathrm{~h}$. That is to say, the use of unmilled rice husk is convenient for the enzymatic hydrolysis and grinding is not necessary, thus implying a decrease in processing costs. The reduction in the particle size and the alkaline pretreatment allow increasing the internal surface area of cellulose, decreasing its crystallinity and degree of polymerization. ${ }^{38}$ All these effects facilitate the accessibility of enzymes to the substrate due to the increase in surface area available to the enzymes, leading to a faster process. $^{39}$

Different authors have reported various results for the enzymatic hydrolysis of biomass, as can be seen in Table 3.

Many factors can influence the performance of enzymatic hydrolysis, namely the type of biomass, enzymatic load, the cocktail of enzymes, and hydrolysis time, but the severity of the pretreatment seems to be of the greatest importance. In this work, yields of $35.5 \%$ for unmilled rice husk and $36.6 \%$ for ground husk were obtained. Table 3 shows that hydrolysis yields between $20 \%$ and $50 \%$ have been reported for rice husk, pretreated with steam explosion, alkaline peroxide, acids at high temperatures, and with higher enzyme dosages and times.

Table 1

Characterization of pretreated rice husk (milled and unmilled)

\begin{tabular}{lcc}
\hline $\begin{array}{l}\text { Component } \\
(\%) \pm \mathrm{SD}\end{array}$ & $\begin{array}{c}\text { Milled pretreated rice } \\
\text { husk }\end{array}$ & $\begin{array}{c}\text { Unmilled pretreated } \\
\text { rice husk }\end{array}$ \\
\hline Lignin & $16.68 \pm 0.09$ & $14.91 \pm 0.26$ \\
Glucans & $54.50 \pm 0.61$ & $51.86 \pm 1.20$ \\
Xylans & $20.83 \pm 0.10$ & $20.50 \pm 0.50$ \\
Arabinans & $1.75 \pm 0.10$ & $1.37 \pm 0.00$ \\
Ashes & $6.28 \pm 0.47$ & $6.00 \pm 0.00$ \\
\hline
\end{tabular}

Table 2

Enzymatic hydrolysis results for milled and unmilled rice husks

\begin{tabular}{lcccc}
\hline & \multicolumn{2}{c}{ Milled rice husk } & \multicolumn{2}{c}{ Unmilled rice husk } \\
\cline { 2 - 5 } Time & $\begin{array}{c}\text { Glucose } \\
\text { concentration } \\
(\mathrm{g} / \mathrm{L}) \pm \mathrm{SD}\end{array}$ & $\begin{array}{c}\text { Glucose yield (total } \\
\text { sugars yield/biomass }) \\
(\%)\end{array}$ & $\begin{array}{c}\text { Glucose } \\
\text { concentration } \\
(\mathrm{g} / \mathrm{L}) \pm \mathrm{SD}\end{array}$ & $\begin{array}{c}\text { Glucose yield (total } \\
\text { sugars yield/biomass) } \\
(\%)\end{array}$ \\
\hline $3 \mathrm{~h}$ & $2.97 \pm 0.04$ & $26.5 \pm 0.3(21.3)$ & $3.13 \pm 0.15$ & $27.9 \pm 1.3(21.0)$ \\
$6 \mathrm{~h}$ & $3.74 \pm 0.04$ & $33.4 \pm 0.4(27.4)$ & $3.76 \pm 0.24$ & $33.6 \pm 2.1(25.6)$ \\
$12 \mathrm{~h}$ & $4.10 \pm 0.01$ & $36.6 \pm 0.1(31.7)$ & $3.98 \pm 0.20$ & $35.5 \pm 1.8(28.4)$ \\
$24 \mathrm{~h}$ & $2.66 \pm 0.05$ & $23.7 \pm 0.5(26.3)$ & $3.57 \pm 0.23$ & $31.8 \pm 2.0(29.8)$ \\
$30 \mathrm{~h}$ & $1.88 \pm 0.23$ & $16.8 \pm 2.1(21.2)$ & $2.85 \pm 0.25$ & $25.4 \pm 2.3(24.6)$ \\
\hline
\end{tabular}


Bioethanol

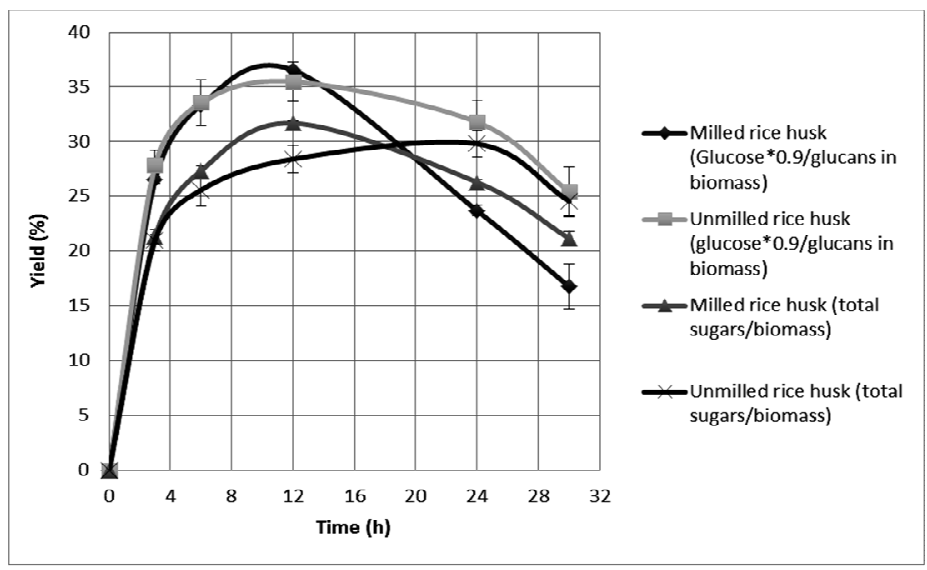

Figure 2: Sugars production in enzymatic hydrolysis of milled and unmilled rice husk

The hydrolysis yields obtained in this work, using milder pretreatment conditions, lower enzyme dosage, and less time, are within the range of those reported in the literature. This is promising in the development of a process, but to improve the yield of fermentable sugars, the use of an excess of enzymes, such as xylanases, could be necessary. On the other hand, other raw materials, such as cassava leaves, guinea grass and sugarcane bagasse, reached hydrolysis yields between $52.9 \%$ and $78.9 \%$, but their pretreatments involved higher temperatures, higher amounts of sodium hydroxide, and longer times than those used of this work.

Regarding the influence of particle size, Table 3 shows that, in the case of rice husk, other authors used smaller particle sizes and obtained lower enzymatic hydrolysis yields that those of this work. These results reinforce our finding that the reduction in particle size does not have any effect that could help increase the enzymatic hydrolysis yields.

Bioethanol production decreased after 13 hours, possibly because of the reduction of sugars in the medium owing to the increase in the microbial population. Another cause could be the accumulation of sugars, which leads to an inhibition in the generation of the final product. ${ }^{46}$

\section{Evaluation of the type of bioethanol production process}

Table 4 shows the average concentration of bioethanol and bioethanol yields in the SHF and SSF processes using SC 1181 yeast. The evolution of the yields of both processes is better shown in Figure 3. Maximal ethanol production in the SHF occurs in approximately 12 hours and then begins to decrease. On the contrary, the SSF process takes 72 hours to obtain the highest concentration, which continues growing. The rapid conversion to ethanol in the SHF process is produced because the sugars are available from the beginning. However, it must be taken into account that the previous hydrolysis process consumed 12 hours. On the contrary, the slow release of sugars from the SSF process makes the conversion to ethanol slower, but in turn, it is maintained over time, achieving higher yields.

The SSF process does not present inhibition of sugars as the SHF, because the microorganisms consume the sugars as they are generated. The constant production of bioethanol is also observed after 72 hours, which suggests that it is possible to obtain higher yields increasing time, which makes this process more promising than the SHF. Table 5 shows the bioethanol yields reported in the literature and in this work for the SSF process.

The bioethanol yield (obtained/theoretical value) achieved in this work was approximately $38.2 \%$, using $1 \%$ hydrolyzable cellulose in $72 \mathrm{~h}$ for the SSF process. As shown in Table 5, Saccharomyces cerevisiae IMRL-1181 gives a similar yield to those reported by Ayeni et al. ${ }^{37}$ and Montipó et al. ${ }^{45}$ using soft alkaline peroxide and steam explosion as pretreatment, respectively, and similar enzymatic charges in the SSF process. Thus, treatments with greater severity produce higher yields. ${ }^{13}$

The causes of low production can be various. While cellulose was saccharified, part of the microorganisms could have died because of lack of substrate, if the glucose production was slow. Moreover, the substrate was possibly used mainly for the growth of microbial biomass. 


\section{ANA MARÍA ARISMENDY PABÓN et al.}

Table 3

Comparison of enzymatic hydrolysis yields for different pretreatments and biomasses in SHF

\begin{tabular}{|c|c|c|c|c|c|c|c|}
\hline $\begin{array}{l}\text { Raw material (EH } \\
\text { substrate concentration) }\end{array}$ & Pretreatment & $\begin{array}{l}\text { EH time } \\
\text { (h) }\end{array}$ & Particle size & Enzymatic load & $\begin{array}{l}\text { Yield of sugars }(\%) \\
\text { enzymatic hydrolysis }\end{array}$ & $\begin{array}{l}\text { Yield of bioethanol (\%) } \\
\text { fermentation time }\end{array}$ & Ref. \\
\hline $\begin{array}{l}\text { Cassava leaves } \\
(8 \% \mathrm{p} / \mathrm{v})\end{array}$ & $\begin{array}{l}\text { Alkaline }(10 \% \mathrm{p} / \mathrm{v} \text { substrate, } 4.5 \% \\
\left.\mathrm{p} / \mathrm{v} \mathrm{NaOH}, 121^{\circ} \mathrm{C}, 60 \mathrm{~min}\right)\end{array}$ & 18 & $0.6 \mathrm{~mm}$ & 18.96 FPU/g substrate, Acellerase 1500 & $\begin{array}{l}52.9 \% \text { (total } \\
\text { sugars/biomass) }\end{array}$ & $\begin{array}{l}88.5 \%, \text { SHF (Saccharomyces } \\
\text { cerevisiae, } 98 \mathrm{~h})\end{array}$ & 25 \\
\hline $\begin{array}{l}\text { Guinea grass (Panicum } \\
\text { maximum) } \\
(5 \% \mathrm{p} / \mathrm{p})\end{array}$ & $\begin{array}{l}\text { Acid }\left(\mathrm{H}_{2} \mathrm{SO}_{4} 12 \% \mathrm{p} / \mathrm{p} \text { substrate, }\right. \\
\left.1.5 \% \mathrm{p} / \mathrm{v} \mathrm{H}_{2} \mathrm{SO}_{4}, 130^{\circ} \mathrm{C}, 60 \mathrm{~min}\right)\end{array}$ & 48 & $2 \mathrm{~mm}$ & $\begin{array}{l}25 \mathrm{BHU} / \mathrm{g} \text { substrate } \\
0.27 \mathrm{CBU} / \mathrm{g} \text { substrate (Novozymes } \\
\text { cellulases y } \beta \text {-glucosidases }\end{array}$ & $\begin{array}{l}38 \% \text { (total } \\
\text { sugars/biomass) }\end{array}$ & & 40 \\
\hline $\begin{array}{l}\text { Sugarcane bagasse } \\
(5 \% \mathrm{w} / \mathrm{w})\end{array}$ & $\begin{array}{l}\text { Steam explosion } \\
\left(200-215-230^{\circ} \mathrm{C}, 5 \mathrm{~min}\right)\end{array}$ & 72 & -- & $\begin{array}{l}15 \mathrm{FPU} / \mathrm{g} \text { substrate of cellulase mixture, } \\
20 \mathrm{UI} / \mathrm{g} \text { substrate of B-glucosidase } \\
\text { (Novozymes) }\end{array}$ & $\begin{array}{l}60 \%\left(200{ }^{\circ} \mathrm{C}\right), 82 \% \\
\left(215{ }^{\circ} \mathrm{C}\right) \text { and } 90 \%(230 \\
\left.{ }^{\circ} \mathrm{C}\right) \text { glucans base }\end{array}$ & & 41 \\
\hline $\begin{array}{l}\text { Sugarcane bagasse } \\
\text { (solid:liquid: } \\
1: 10 \mathrm{w} / \mathrm{v} \text { ) }\end{array}$ & $\begin{array}{l}\text { Sequential: Hydrothermal }(170 \mathrm{C} \text {, } \\
\text { liquid:solid: } 6: 1,60 \mathrm{~min}) \text { and } \\
\text { Organosolv (ethanol:water: } 1: 1 \\
\text { v/v, } 160 \text { and } 190 \mathrm{C}, 30-150 \mathrm{~min} \text {, } \\
\text { liquid:solid: } 3: 9 \text { ) }\end{array}$ & 48 & Pulp & $\begin{array}{l}10 \text { FPU cellulases (from Trichoderma } \\
\text { reesei) and } 20 \mathrm{IU} \text { of } \beta \text {-glucosidase (from } \\
\text { Aspergillus niger)/g substrate }\end{array}$ & $\begin{array}{l}61.8-78.9 \% \text { (cellulose } \\
\text { base) }\end{array}$ & & 42 \\
\hline $\begin{array}{l}\text { Rice husk } \\
(3 \% \mathrm{w} / \mathrm{v})\end{array}$ & $\begin{array}{l}\text { Alkaline peroxide } \\
\text { (biomass:liquid: } 1: 20, \mathrm{pH} 11.5 ; \\
\text { optimum conditions: } \mathrm{H}_{2} \mathrm{O}_{2} 1.38 \% \\
\text { v/v, } 109^{\circ} \mathrm{C}, 2 \mathrm{~h}\end{array}$ & 24 & $1.18 \mathrm{~mm}$ & $\begin{array}{l}35 \text { FPU/g substrate cellulase enzyme } \\
\text { (from Trichoderma reesei) }\end{array}$ & $20.5 \%$ biomass base & & 37 \\
\hline $\begin{array}{l}\text { Rice husk } \\
(10 \% \mathrm{w} / \mathrm{v})\end{array}$ & $\begin{array}{l}\text { Acid - optimum conditions: } 5 \% \\
\text { p/p substrate, } 0.3 \% \mathrm{p} / \mathrm{v} \mathrm{H}_{2} \mathrm{SO}_{4} \\
152{ }^{\circ} \mathrm{C}, 33 \mathrm{~min}\end{array}$ & 48 & $\begin{array}{l}<10 \mathrm{~mm} \times \\
1 \mathrm{~mm}\end{array}$ & $\begin{array}{l}40 \mathrm{FPU} / \mathrm{g} \text { glucans endoglucanases, } 18 \\
\text { FPU/g biomass cellobiase, Novozymes } \\
\text { endoglucanase:cellobiase 10:1 }\end{array}$ & $\begin{array}{l}\text { About } 50 \% \text { glucans } \\
(22.2 \% \text { biomass base })\end{array}$ & $\begin{array}{l}\text { SHF (Saccharomyces } \\
\text { cerevisiae, } 72 \mathrm{~h} \text { ) } 4.42 \mathrm{~g} / \mathrm{L} \\
\text { bioethanol, } 84 \% \text { conversion } \\
\text { efficiency }\end{array}$ & 43 \\
\hline $\begin{array}{l}\text { Rice husk } \\
(10 \% \mathrm{w} / \mathrm{v})\end{array}$ & $\begin{array}{l}\text { Acid - optimum conditions }(10 \% \\
\text { w/v substrate, } 1 \% \text { sulfuric acid, } \\
\left.121{ }^{\circ} \mathrm{C}, 1 \mathrm{~h}\right)\end{array}$ & 48 & $\begin{array}{c}\text { Flour } \\
\text { (between } 80 \\
\text { and } 100 \\
\text { mesh) } \\
\end{array}$ & $40 \mathrm{FPU} / \mathrm{g}$ glucans of Cellic CTeC 2 & $79.8 \%$ glucans base & & 44 \\
\hline $\begin{array}{l}\text { Rice husk } \\
(10 \% \mathrm{w} / \mathrm{v})\end{array}$ & $\begin{array}{l}\text { Steam explosion: } 205^{\circ} \mathrm{C}, 11.5 \\
\text { min }\end{array}$ & 72 & -- & $\begin{array}{l}20 \mathrm{FPU} / \mathrm{g} \text { substrate, Celluclast } \\
\text { cellulolytic complex }\end{array}$ & $37.2 \%$ glucans base & -- & 45 \\
\hline $\begin{array}{l}\text { Rice husk } \\
(2 \% \mathrm{w} / \mathrm{v})\end{array}$ & $\begin{array}{l}\text { Alkaline } \\
(10 \% \mathrm{w} / \mathrm{v} \text { substrate, } 3 \% \mathrm{p} / \mathrm{v} \\
\left.\mathrm{NaOH}, 121^{\circ} \mathrm{C}, 60 \mathrm{~min}\right)\end{array}$ & 12 & $\begin{array}{l}<2 \mathrm{~mm} \\
\text { (milled) }\end{array}$ & $\begin{array}{l}30 \mathrm{FPU} / \mathrm{g} \text { glucans Cellic CTec2 (about } \\
16 \mathrm{FPU} / \mathrm{g} \text { substrate) }\end{array}$ & $\begin{array}{l}35.5 \% \text { glucans base } \\
\text { (unmilled), } 36.6 \% \\
\text { glucans base (milled) }\end{array}$ & $\begin{array}{l}\text { SHF (Saccharomyces cerevisiae } \\
1181), 13 \mathrm{~h}, 35.3 \%\end{array}$ & $\begin{array}{r}\text { This } \\
\text { work }\end{array}$ \\
\hline
\end{tabular}


Table 4

Comparison of hydrolysis followed by fermentation (SHF) vs. simultaneous saccharification and fermentation (SSF), using Saccharomyces cerevisiae 1181

\begin{tabular}{lcccc}
\hline \multirow{2}{*}{ Time } & \multicolumn{3}{c}{ SHF } & \multicolumn{2}{c}{ SSF } \\
\cline { 2 - 5 } & $\begin{array}{c}\text { Bioethanol concentration } \\
(\mathrm{g} / \mathrm{L})\end{array}$ & $\begin{array}{c}\text { Bioethanol yield } \\
(\%)\end{array}$ & $\begin{array}{c}\text { Bioethanol concentration } \\
(\mathrm{g} / \mathrm{L})\end{array}$ & $\begin{array}{c}\text { Bioethanol yield } \\
(\%)\end{array}$ \\
\hline $12 \mathrm{~h}$ & $2.00 \pm 0.01$ & $35.3 \pm 0.2$ & $1.16 \pm 0.08$ & $20.3 \pm 1.4$ \\
$20 \mathrm{~h}$ & $1.90 \pm 0.03$ & $33.4 \pm 0.5$ & $1.89 \pm 0.12$ & $33.2 \pm 2.0$ \\
$24 \mathrm{~h}$ & $1.72 \pm 0.04$ & $30.2 \pm 0.7$ & $1.85 \pm 0.16$ & $32.6 \pm 2.9$ \\
$36 \mathrm{~h}$ & & & $1.94 \pm 0.01$ & $34.2 \pm 0.2$ \\
$48 \mathrm{~h}$ & & & $2.02 \pm 0.01$ & $35.6 \pm 0.2$ \\
$72 \mathrm{~h}$ & & & $2.17 \pm 0.03$ & $38.2 \pm 0.5$ \\
\hline
\end{tabular}

Table 5

Comparison of reported bioethanol yields obtained by SSF processes

\begin{tabular}{|c|c|c|c|c|c|}
\hline $\begin{array}{l}\text { Raw material } \\
\text { (amount of biomass) }\end{array}$ & Pretreatment & Enzymatic load & Process & $\begin{array}{l}\% \text { Ethanol yield (\% } \\
\text { of theoretical yield) }\end{array}$ & Ref. \\
\hline $\begin{array}{l}\text { Oil palm bunches } \\
(10 \%)\end{array}$ & $\begin{array}{l}\text { Two steps: } 0.2 \mathrm{M} \text { sulfuric acid, } 121 \\
{ }^{\circ} \mathrm{C}, 53 \mathrm{~min} ; \\
5 \% \mathrm{w} / \mathrm{v} \mathrm{NaOH}, 121^{\circ} \mathrm{C}, 20 \mathrm{~min}\end{array}$ & $\begin{array}{l}\text { Cellulose and B-glucosidase 5:1 (20 FPU/g and } \\
4 \mathrm{U} / \mathrm{g} \text { of substrate; optimal conditions: } 12.24 \% \\
\text { w/v, } \mathrm{pH} 4.5 \text {, yeast } 2.04 \% \mathrm{v} / \mathrm{v}, 36.94{ }^{\circ} \mathrm{C}\end{array}$ & $\begin{array}{l}\text { Kluyveromyces marxianus, } \\
48 \mathrm{~h}\end{array}$ & $68.6 \%$ & 47 \\
\hline $\begin{array}{l}\text { Green coconut husks } \\
(4 \%)\end{array}$ & $\begin{array}{l}\text { Autohydrolysis pretreatment } \\
\text { (solid/liquid: } 1: 10 \mathrm{v} / \mathrm{w}, 200{ }^{\circ} \mathrm{C}, 50 \\
\text { min (severity factor: } 4.64 \text { ) }\end{array}$ & $\begin{array}{l}30 \mathrm{FPU} / \mathrm{g} \text { substrate Cellic CTec2 and } 130 \mathrm{IU} / \mathrm{g} \\
\text { substrate Cellic HTec2 }\end{array}$ & $\begin{array}{l}\text { S. cerevisiae, } P \text {. stipitis, } Z \text {. } \\
\text { mobilis, } 48 \mathrm{~h}\end{array}$ & $\begin{array}{l}86.90 \%, 84.19 \% \\
85.26 \% \\
\text { respectively }\end{array}$ & 48 \\
\hline $\begin{array}{l}\text { Cane bagasse } \\
(16 \%)\end{array}$ & Steam explosion, $215^{\circ} \mathrm{C}, 5 \mathrm{~min}$ & $\begin{array}{l}20 \mathrm{FPU} / \mathrm{g} \text { sustrate Cellulase mixture and } 20 \\
\text { UI/g substrate B-Glucosidase (Novozymes) }\end{array}$ & $\begin{array}{l}\text { S. cerevisiae, Ethanol Red, } \\
72 \mathrm{~h}\end{array}$ & $63.1 \%$ & 41 \\
\hline $\begin{array}{l}\text { Rice husk } \\
(3 \%)\end{array}$ & $\begin{array}{l}\text { Alkaline peroxide (biomass:liquid: } \\
\text { 1:20, pH 11.5. Optimum conditions: } \\
\mathrm{H}_{2} \mathrm{O}_{2} 1.38 \% \text { v/v, } 109^{\circ} \mathrm{C}, 2 \mathrm{~h}\end{array}$ & $\begin{array}{l}35 \mathrm{FPU} / \mathrm{g} \text { substrate of cellulase of Trichoderma } \\
\text { reesei }\end{array}$ & $\begin{array}{l}\text { Saccharomyces cerevisiae, } 96 \\
\mathrm{~h}\end{array}$ & $33 \%$ & 37 \\
\hline $\begin{array}{l}\text { Rice husk } \\
(20 \%)\end{array}$ & Steam explosion $\left(205^{\circ} \mathrm{C}, 11.5 \mathrm{~min}\right)$ & $20 \mathrm{FPU} / \mathrm{g}$ substrate of Celluclast $1.5 \mathrm{~L}$ & $\begin{array}{l}\text { Saccharomyces cerevisiae } \\
\text { CAT }-1,72 \mathrm{~h}\end{array}$ & $34.8 \%$ & 45 \\
\hline $\begin{array}{l}\text { Rice straw } \\
(8 \%)\end{array}$ & $\begin{array}{l}\text { Acid }\left(100 \mathrm{mg} \mathrm{H}_{2} \mathrm{SO}_{4} / \mathrm{g} \text { dry matter; }\right. \\
1: 10 \text { dry matter/acid solution; } 120 \\
\left.{ }^{\circ} \mathrm{C}, 30 \mathrm{~min}\right)\end{array}$ & $\begin{array}{l}25 \text { FPU/g substrate Cellubrix and } 25 \mathrm{UI} / \mathrm{g} \\
\text { substrate Novozyme } 188\end{array}$ & $\begin{array}{l}\text { K. marxianus NRRL Y-6860, } \\
45^{\circ} \mathrm{C}, 6 \mathrm{~h}\end{array}$ & $82 \%$ & 20 \\
\hline $\begin{array}{l}\text { Rice husk } \\
(2 \%)\end{array}$ & $\begin{array}{l}\text { Alkaline }(10 \% \mathrm{w} / \mathrm{v} \text { substrate, } 3 \% \mathrm{p} / \mathrm{v} \\
\left.\mathrm{NaOH}, 121^{\circ} \mathrm{C}, 60 \mathrm{~min}\right)\end{array}$ & 30 FPU/g glucans Cellic CTec2 & $\begin{array}{l}\text { Saccharomyces cerevisiae } \\
\text { IMRL- } 1181,72 \mathrm{~h} \\
\text { Saccharomyces cerevisiae } \\
\text { IMRL- } 1507,48 \mathrm{~h}\end{array}$ & $\begin{array}{l}38.2 \% \\
43.9 \%\end{array}$ & $\begin{array}{l}\text { This } \\
\text { work }\end{array}$ \\
\hline
\end{tabular}




\section{ANA MARÍA ARISMENDY PABÓN et al.}

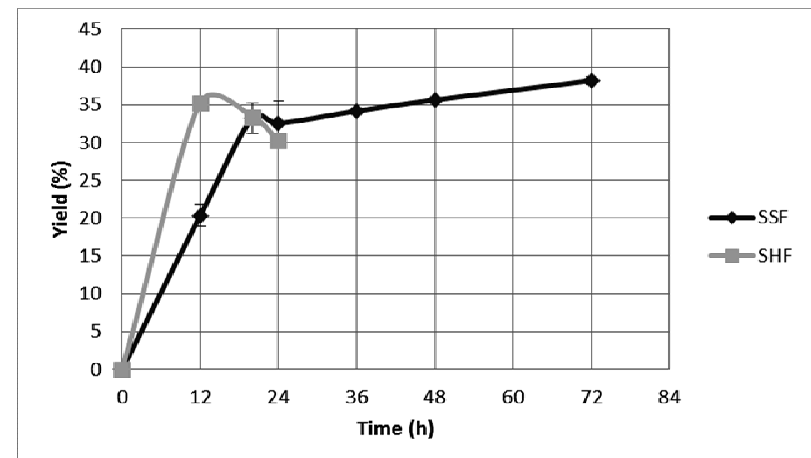

Figure 3: Comparison of hydrolysis followed by fermentation (SHF) and simultaneous hydrolysis and fermentation (SSF) using SC 1181 yeast

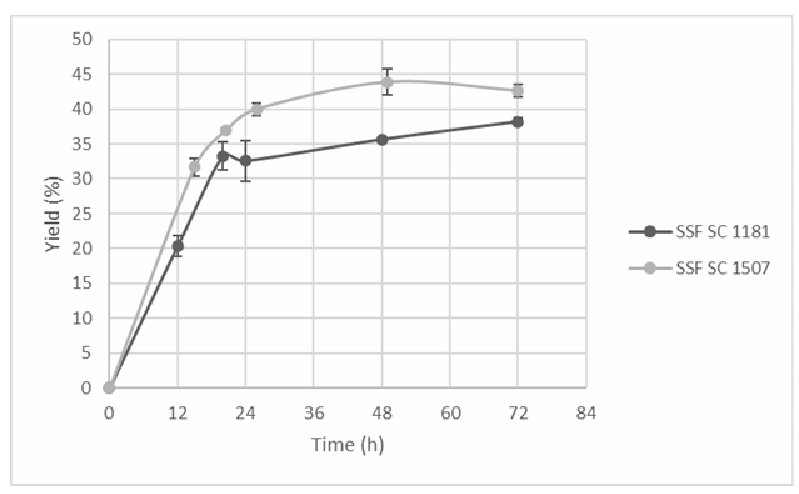

Figure 4: Yields of bioethanol from milled and pretreated husk by SSF using SC 1181 and SC 1507 yeasts

Finally, there may also be inhibition in the generation of the final product, such as bioethanol, since pentoses are found in the medium, which are not assimilated by Saccharomyces cerevisiae. The above considerations suggest the possible use of microorganisms, such as Pichia stiptis, could allow the exploitation of hexoses and pentoses to obtain better bioethanol yields.

\section{Influence of yeast type}

The yield of bioethanol in the SSF process applied to milled and pretreated rice husk, using the two studied yeasts (SC 1181 and SC 1507), are shown in Figure 4.

SC 1507 yeast showed the best performance at all times, obtaining the maximum yield of bioethanol of $44 \%$ in $48 \mathrm{~h}$, which is $6 \%$ higher that obtained with SC 1181 in 72 h. Conversely, in the case of the SC1181 yeast, the amount of bioethanol continued to increase until $72 \mathrm{~h}$, although without matching the level of the other.
Significant amounts of hemicelluloses and lignin remained in the biomass owing to the light alkaline pretreatment, which hindered the efficiency of the $\mathrm{EH}$, and consequently, the bioethanol production. However, bioethanol yields of about $44 \%$ were obtained in 48 hours (from that moment, it remained constant).

For a rice husk biorefinery, the proposed processing shows an interesting perspective. On the one hand, the pretreatment extracts $87 \%$ of the original silica from the husk, which constitutes $24 \%$ of the material. Silica can be separated from the spent liquor and marketed to the electronics industry. Also, after SSF bioethanol production (30\% yield), $70 \%$ of the remaining solid material will present high porosity, making it an ideal material for the production of activated carbon.

In another scenario, the sugars with five carbon atoms can be used for the production of xylitol, using wild, non-genetically modified yeasts, taking advantage of all the hydrolyzed carbohydrates. Lastly, the solid residue of the SSF or SHF processes, containing microorganisms and 
enzymes, can be used as organic fertilizer in agriculture.

\section{CONCLUSION}

The yields of glucose production in the $\mathrm{EH}$ process are similar for both milled and unmilled rice husk, although a little more glucose is generated with the ground husk. However, the costs of grinding have to be evaluated.

If the sum of the hydrolysis and fermentation times is considered, the SHF process is less efficient. Besides, the bioethanol production reaches a maximum and drops rapidly. Meanwhile, the production of bioethanol in the SSF process is slightly higher and continues to increase after 72 hours, so it could be increased with an optimized process.

The yeast Saccharomyces cerevisiae 1507 performed best at all times, and the maximum bioethanol production was obtained in $48 \mathrm{~h}$ (about $44 \%)$.

The ethanol yields obtained are acceptable, given the processing time, the pretreatment under soft conditions, and the moderate enzyme load used in the process.

ACKNOWLEDGMENTS: Thanks to CONICET (National Council of Scientific and Technical Research of Argentina), for the postgraduate scholarship granted to Ana María Arismendy.

\section{REFERENCES}

1 R. Chandra, H. Takeuchi, T. Hasegawa and R. Kumar, Energy, 43, 1 (2012), https://doi.org/10.1016/j.energy.2012.04.029

2 Y. Sun and J. Cheng, Bioresour. Technol., 83, 1 (2002), https://doi.org/10.1016/S0960-8524(01)002127

3 P. Binod, R. Sindhu, R. R. Singhania, S. Vikram, L. Devi et al., Bioresour. Technol., 101, 13 (2010), https://doi.org/10.1016/j.biortech.2009.10.079

4 D. Qing, S. Keat and R. M. Gersberg, J. Environ. Manag., $\quad$ 91, $\quad 8 \quad$ (2010), https://doi.org/10.1016/j.jenvman.2010.03.012

5 FAO, Seguimiento del mercado del Arroz de la FAO Abril de 2017, available at http://www.fao.org/3/I9243ES/i9243es.pdf

6 M. Moniruzzaman, Appl. Biochem. Microbiol., 59, 3 (1996), https://doi.org/10.1007/BF02783570

7 E. M. Rubin, Nature, 454, 8 (2008), https://doi.org/10.1038/nature07190

8 B. C. Saha and A. Cotta, Enzyme Microb. Technol., 41, 4 (2007), https://doi.org/10.1016/j.enzmictec.2007.04.006

9 A. Stomp and J. J. Cheng, Clean Soil Air Water, 37, 1 (2009), https://doi.org/10.1002/clen.200800210
10 P. Kumar, D. M. Barrett, M. J. Delwiche and P. Stroeve, Ind. Eng. Chem. Res., 48, 8 (2009), https://doi.org/10.1021/ie801542g

11 C. Gao, W. Xiao, G. Ji, Y. Zhang, Y. Cao et al., Bioresour. Technol., 241, 1 (2017), https://doi.org/10.1016/j.biortech.2017.04.115

12 R. Ravindran and A. K. Jaiswal, Bioresour. Technol., $\quad$ 199, $10 \quad$ (2016), https://doi.org/10.1016/j.biortech.2015.07.106

${ }^{13}$ L. Favaro, M. J. Viktor, S. Rose, H. ViljoenBloom, M. van Zyl et al., Biotechnol. Bioeng., 112, 9 (2015), https://doi.org/10.1002/bit.25591

14 J. S. Kim, Y. Y. Lee and T. H. Kim, Bioresour. Technol., 199, 42 (2016), https://doi.org/10.1016/j.biortech.2015.08.085

15 C. Zhao, X. Qiao, Y. Cao and Q. Shao, Fuel, 205, 10 (2017), https://doi.org/10.1016/j.fuel.2017.05.073

16 B. Tsegaye, C. Balomajumder and P. Roy, Environ. Technol. 40, 9 (2019), https://doi.org/10.1080/09593330.2017.1418911

17 M. Wang, D. Zhou, Y. Wang, S. Wei, W. Yang et al., Fuel, 184, $16 \quad$ (2016), https://doi.org/10.1016/j.fuel.2016. 07.061

18 M. J. Taherzadeh and K. Karimi, BioResources, 2, 4 (2007),

https://ojs.cnr.ncsu.edu/index.php/BioRes/article/view/ BioRes_2_4_707_738_Taherzadeh_Karimi_EnzymeB ased_Hydrol_Ethanol_Review

19 H. Shokrkar and S. Ebrahimi, Biofuel. Bioprod. Biorefin., $\quad \mathbf{1 2}, \quad 5 \quad$ (2018), https://doi.org/10.1002/bbb.1886

20 R. Castro and I. Roberto, Appl. Biochem. Biotechnol., 172, 3 (2014), https://doi.org/10.1007/s12010-013-0612-5

21 M. C. Area and M. E. Vallejos, "Biorefinery from Lignocellulosic Waste. Conversion of Waste to High Value Products", Acádemica Spanish Editorial, Saarbrücken, Germany, 2012, pp. 163-164, https://www.researchgate.net/publication/262933028_ Biorrefineria_a_partir_de_residuos_lignocelulosicos_ Conversion_de_residuos_a_productos_de_alto_valor 22 J. Kumar, R. Saini and L. Tewari, 3 Biotech., 5, 4 (2015),

https://link.springer.com/article/10.1007/s13205-0140246-5

${ }^{23}$ F. Lorenzo, C. Lorenzo, B. Marina, P. Valentino, Z. W. Heber et al., Bioresour. Technol., 244, 1 (2017), http://dx.doi.org/10.1016/j.biortech.2017.07.108

24 Ch. Zhao, Z. Zou, J. Li, H. Jia, L. Johannes et al., Renew. Energ., 118, 4 (2018), https://doi.org/10.1016/j.renene.2017.11.001

25 L. López, Master's Thesis, University of Antioquia, Colombia, 2012

26 A. Sluiter, B. Hames, D. Hyman, C. Payne, R. Ruiz et al., Determination of total solids in biomass and total dissolved solids in liquid process samples, Laboratory Analytical Procedure (NREL), Issue Date 2008, https://www.nrel.gov/docs/gen/fy08/42621.pdf

27 A. Sluiter, B. Hames, R. Ruiz, C. Scarlata, J. A. 
Sluiter et al., Determination of structural carbohydrates and lignin in Biomass, Laboratory Analytical Procedure (NREL), Issue Date 2008, https://www.nrel.gov/docs/gen/fy13/42618.pdf

28 A. Sluiter, B. Hames, R. Ruiz, C. Scarlata, J. Sluiter et al., Determination of Ash in Biomass, Laboratory Analytical Procedure (NREL), Issue Date 2008, https://www.nrel.gov/docs/gen/fy08/42622.pdf

29 A. Sluiter, R. Ruiz, C. Scarlata, J. Sluiter, D. Templeton et al., Determination of Extractives in Biomass, Laboratory Analytical Procedure (NREL), Issue Date 2008, https://www.nrel.gov/docs/gen/fy08/42619.pdf

30 T. K. Ghose, IUPAC, 59, 2 (1987), https://doi.org/10.1351/pac198759020257

31 N. Dowe and J. McMillan, SSF Experimental Protocols - Lignocellulosic Biomass Hydrolysis and Fermentation, Laboratory Analytical Procedure (NREL), Issue Date 2008, https://www.nrel.gov/docs/gen/fy08/42630.pdf

32 A. M. Arismendy, M. Sequeira, F. Felissia, E. Chamorro and M. C. Area, RTyC, 30, 1 (2017), http://rtyc.utn.edu.ar/index.php/rtyc/article/view/179

33 A. M. Arismendy, A. F. Restrepo, W. Alcaraz, E. Chamorro and M. C. Area, RECyT, 32, 2 (2019), https://doi.org/10.36995/j.recyt.2019.32.010

34 M. Selig, N. Weiss and Y. Ji, Enzymatic Saccharification of Lignocellulosic Biomass, Laboratory Analytical Procedure (NREL), Issue Date 2008

35 M. Takano and K. Hoshino, Bioresour. Bioprocess., $\quad 5, \quad 16 \quad$ (2018), https://doi.org/10.1186/s40643-018-0203-y

36 C. Zhao, X. Qiao, Y. Cao and Q. Shao, Fuel, 205, 184 (2017), https://doi.org/10.1016/j.fuel.2017.05.073

37 A. O. Ayeni, M. O. Daramola, P. T. Sekoai, O. Adeeyo, M. J. Garba et al., Cellulose, 25, 4 (2018), https://doi.org/10.1007/s10570-018-1714-6
38 N. L. López, A. Acosta and Z. R. Gelves, Rev. Fac. Ing. Univ. Antioquia, 69, 317 (2013), https://www.redalyc.org/pdf/430/43029812024.pdf

39 D. N. Thompson, H. Chen and H. E. Grethlein, Bioresour. Technol., 39, 2 (1992), https://doi.org/10.1016/0960-8524(92)90135-K

40 C. R. Castillo-Saldarriaga and M. E. VelásquezLozano, Bio. Agro., 16, 1 (2018), http://www.scielo.org.co/pdf/bsaa/v16n1/1692-3561bsaa-16-01-00068.pdf

41 I. Amores, I. Ballesteros, P. Manzanares, F. Sáez, G. Michelena et al., Electron. J. Energ. Environ., 1, 1 (2013), https://doi.org/10.7770/ejee-V1N1-art486

42 M. E. Vallejos, M. D. Zambon and M. C. Area, Waste Biomass Valorif., 10, 4 (2019), https://doi.org/10.1007/s12649-019-00657-2

${ }^{43}$ E. P. Dagnino, E. R. Chamorro, S. D. Romano, F. E. Felissia and M. C. Area, Ind. Crop. Prod., 42, 1 (2013), https://doi.org/10.1016/j.indcrop.2012.06.019

44 C. de C. Lamb, B. M. Zacarias da Silva, D. de Souza, F. Fornasier, L. Brixner Riça et al., Chem. Eng. Commun., $\quad 205, \quad 6 \quad 618$, https://doi.org/10.1080/00986445.2017.1422495

45 S. Montipó, I. Ballesteros, R. Fontana, S. Liu, M. Ballesteros et al., Cellulose, 26, 12 (2019), https://doi.org/10.1007/s10570-019-02571-1

46 Y. Xing, L. Bu, D. Sun, Z. Liu, S. Liu et al., Fuel, 177, 8

(2016), https://doi.org/10.1016/j.fuel.2016.03.024

47 S. Sukhang, S. Ch. T. Reungpeerakul and Ch. Sangwitchien, Cellulose, 27, 2 (2019), https:10.1007/s10570-019-02778-2

48 F. A. Goncalves, H. A. Ruiz, E. S. dos Santos, J. A. Teixeira, G. R. de Macedo, Ind. Crop. Prod., 77, 1 (2015), https://doi.org/10.1016/j.indcrop.2015.06.041 